Digital Press Social Sciences and Humanities

The Attractiveness of Krebet Tourism Village: Applying Components of Tourism Analysis

Dyah Widyastuti and Theresia Rasika Dharmesti

Proceeding of Indonesia Heritage Tourism Forum 2019 (IHTF 2019)

Dewi Pratika Ayu Dhira Pradati (eds) 


\title{
The Attractiveness of Krebet Tourism Village: Applying Components of Tourism Analysis
}

\author{
Dyah Widyastuti*, Theresia Rasika Dharmesti \\ Center for Tourism Studies, Universitas Gadjah Mada, Yogyakarta, Indonesia \\ *e-mail: dwidiyastuti@ugm.ac.id
}

\begin{abstract}
Krebet Tourism Village is one of the tourism villages that categorized as tourism heritage. Located in Yogyakarta Special Region, a province in Indonesia famous by its culture, Krebet has a name for the best Batik Wooden Craft maker. For almost 30 years, Batik Wooden Craft has been bringing economic development into Krebet Village. Accordingly, people visit Krebet mainly for shopping Batik Wooden Craft and learning the making process of it. This study aims to observe Krebet tourism components that consist of attractions, accessibilities, amenities, and ancillaries; and identify Krebet tourism development efforts in order to measure the readiness of tourism destination. Conducting tourism components analysis with descriptive analysis in the qualitative approach, the results have identified Krebet Tourism village has another tourism potential: natural tourist attraction, heritage, local event, and local performance. The other tourism potentials in Krebet Tourism Village have indicated need some developments primarily in communication and facility. Besides, Krebet tourism development effort depicted the effort that has not optimized. This tourism village needs maintenance, improvement, and continuity in order to catch more visitors to visit Krebet Tourism Village. With collaboration between Krebet residents, government, and some CSR programs, economic development will be sustained by creating integrated tourism products in natural and cultural experiences through tourism village.
\end{abstract}

\section{Keywords}

components of tourism, tourism attractiveness, tourism village

\section{Introduction}

Tourism is the industry that has been chosen as the focus to develop in Indonesia. According to the newest DI. Yogyakarta Bank Indonesia's regional office annual report (D.I. Yogyakarta Bank Indonesia Regional Office, 2018), tourism has contributed about 55\% of the regional income of the Yogyakarta Special Region. Behind this data, tourism positively affects another business such as hospitality, transportation, and consumer product industry. Besides the famous natural tourist attractions, the visitors also love to learn about Javanese culture in Yogyakarta. Thus, a tourist village is developed in order to combine natural and cultural aspects into one experience.

Special Region of Yogyakarta has 131 tourist village in total (Tourism Department of Yogyakarta, 2017). Elaboration is from the five districts in this province, those are Sleman with 38 tourism villages, Bantul with 39 tourism villages, Kulon Progo with 10 tourism villages, Gunung Kidul with 17 tourism villages, and Yogyakarta City with 17 tourism villages. Currently, Bantul has the biggest number of tourism villages. It is encouraged by the city brand of Bantul that renowned for its handcraft uniqueness. As stated by Bantul Government, this district is the center of the handicraft industry in the Special Region of Yogyakarta Province. Mostly, souvenirs that the tourists bring from Yogyakarta Province as the gifts for their family and friends are made in Bantul. In conclusion, the uniqueness of Bantul's handcraft attracts the tourists to learn how to make their own by visiting the villages where the products are made, thus their gifts will be more personal.

One of the famous villages that create unique handcraft is Krebet. In Krebet Tourism Village, the people innovate Batik into fancy things. On the first time it created, ancient Javanese drew a fabric with a special pattern that depicts human life. Because the fabric is made with such philosophy, the fabric was only for people who had a high position in society. Nowadays everyone wears Batik as their daily fashion in the 
various cut. While Batik is a name of clothing pattern, people in Krebet Tourism Village draw it on wooden functional items.

In 1990, this idea came from their needs to make an attribute for performing a traditional dance, which is a mask. Mask is an important thing in most Javanese traditional dance since the dancers play the role of Javanese puppet called Wayang. The mask has a nice shape just like a human face with beautiful Batik patterns and colors, it seduces people who have a great sense of art to have it. Then one by one Batik Wooden Craft shops are erected in Krebet Tourism Village. They sell various kinds of Batik Wooden Craft, from small souvenirs until furniture. All are handmade by the villagers. At first, Yogyakarta's visitors only shop Batik Wooden Craft products from some gift shop in the city. As time goes by, with the possibilities to reach out to the village where the gifts are made, the tourists love to handcraft their own souvenirs. Furthermore, the tourists enjoy the atmosphere of the village and decide to stay longer just to appreciate the nature and culture inside Krebet Tourism Village.

Currently, there are 46 Batik Wooden Craft shops in Krebet Tourism Village. Their existence interprets that Krebet Tourism Village is on growing. At least 10 tourists visit this village for shopping every day. Kelompok Sadar Wisata, an organization to accommodate the visitors, was formed by the regional government in order to optimize tourism potential in each tourist village. In pursuance of Tosun (2000), forms and scale of tourism developed, for instance: scale and levels of tourism development, the market served, and cultural attributes of the local communities are beyond the control of local communities. So that components of tourism analysis that consist of attractions, amenities, accessibilities, and ancillaries are needed to understand the Krebet tourism potentials in the interest of advancing Krebet Tourism Village development. Moreover, the physical aspect, infrastructure, environment, reputation, and safety related to tourism components are assessments for measuring the readiness of the tourism destination (Cooper, Fletcher, Gilbert, Fyall, \& Wanhill, 2005). Specific objectives of this study include: 1) observe Krebet tourism components (attractions, amenities, accessibilities, and ancillaries); 2) identify Krebet tourism development efforts.

\section{Methods}

The qualitative approach was used to reveal the real situation in detail. The data collection method in this research used in-depth-interview and survey with a questionnaire where 46 Batik Wooden Craft business owners in Krebet Tourism Village were interviewed and surveyed. Descriptive analysis was used to observe Krebet tourism components and their tourism development efforts.

\section{Result and Discussion}

\subsection{Krebet Tourism Components}

This study observed Krebet Tourism Village about its natural tourist attraction, culture, heritage, tourism activities, accessibilities, amenities, ancillaries, and the quality of its environment in order to meet the tourist needs. Krebet Tourism Village has 3 natural tourist attractions, they are Curug Pulosari, Bukit Pajangan, and Pohon Krebet. Curug Pulosari is a seasonal waterfall that brings relaxation within its waterfall sounds, fresh air, and natural pond. Although Bukit Pajangan is not exactly located in Krebet Tourism Village, it is easy to reach using bicycle. Bukit Pajangan is a hill near this tourism village. From this hill, the visitors are served by such beautiful views, they are able to see an ocean and the mountains at one point. The third natural tourist attraction in Krebet Tourism Village is Pohon Krebet, a big tree on the main junction of the village. According to the history of the village, the tree has been there for hundred of years. Previously, Krebet Tourism Village was a forest, but the ancestors left one tree as the mark of the village existence, the biggest one. Until now, Pohon Krebet is the icon of the village where some visitors take a portrait.

The existence of Pohon Krebet is not only as a natural tourist attraction but also a heritage. Yale (1991) (in Garrod \& Fyall, 2000) argued that heritage tourism is tourism centered on what people have inherited, which can mean anything from historic buildings, artworks, to the beautiful scenery. The tree remains the Krebet people about the struggle of life and how their ancestors started the village. Meanwhile, today is time for them to continue their ancestor's struggle. Semar, a big statue near Pohon Krebet, also one of the 
heritage in Krebet Tourism Village. Whenever people see the statue, people will recognize that the statue is located in Krebet Tourism Village. Semar is one of Javanese puppet figures that symbolizes prosperity. The statue was made for a cultural festival held by the Bantul government. It was light, made from newspaper. After the festival, people in Krebet built the statue as their icon.

Upacara Merti Dusun, the ceremonial event held once a year, is gratitude for welfare and safety. This ceremony is not only held by Krebet Village but also other villages that taking Javanese culture as their way of life. In the ceremony, people in the village make huge dishes that consist of Tumpeng, a giant portion of yellow coconut rice in a cone shape, with various cooked meats and vegetables. The dishes are made for the guardian god as a thanksgiving for keeping their village away from disaster. Hereafter, people hold the Javanese puppet show for a night. The Javanese puppet show story is a reminder for the residents to always be mindful of life. Even though Krebet Tourism Village is not the only one that holds the ceremony, each village that does the ceremony has a different time to execute the event. Hence, the ceremony will be held at the same Javanese month, yearly Javanese calendar.

Krebet Tourism Village has 10 local art communities in order to look after Javanese art. They are Karawitan which is Javanese traditional music orchestra, Javanese traditional dance, two Jathilan groups which are another Javanese dance that illustrates the move of Javanese myth figure, Macapat which is a singing Javanese song traditionally with no backsound, Gendring which is another kind of Javanese orchestra focused on the rhythm similarly with drum, Hadroh which is Islamic music with rhythm, Ketoprak which is Javanese drama musical, Sholawatan which is acapella Islamic vocal group, and Javanese classical music which is contemporary Javanese music mixed with the acoustic guitar. These local art communities and the local ceremony as mentioned before are Krebet Tourism Village's potential tourism products that should be developed to attract more visitors to stay in their village.

As seen in Table 1, there are some development needs that will be the answer to make Krebet Tourism Village be the famous tourism village in spite of their Batik Wooden Craft products that already attract people to visit. Without promotion, for example, people will not aware of Krebet's tourism potentials. In fact, this tourism village has more than one tourism products to sell. Mainly they need to tell more information about the performances they are able to show and also the cultural ceremony. Especially today people are easy to get information from the internet, however, there is no update information about Krebet Tourism Village.

Table 1 Tourist Attractions in Krebet Village

\begin{tabular}{|c|c|c|c|}
\hline Location & Recreational Activities & Environmental Conditions & Development Needs \\
\hline Curug Pulosari & $\begin{array}{ll}\text { 1. } & \text { Swimming } \\
\text { 2. } & \text { Relaxing } \\
\text { 3. } & \text { Hiking }\end{array}$ & $\begin{array}{l}\text { 1. Fresh and Clean } \\
\text { 2. No Waterfall in the dry } \\
\text { season } \\
\text { 3. No road signs to reach the } \\
\text { destination, only the map } \\
\text { of Krebet Tourism Village } \\
\text { 4. Facilities: parking area, } \\
\text { food stall, fitting room, } \\
\text { bathroom, life buoy } \\
\text { 5. Safety path } \\
\text { 6. Homestay nearby } \\
\text { 7. Tour guide }\end{array}$ & $\begin{array}{l}\text { 1. Using social media for } \\
\text { informing the situation, } \\
\text { whether there is a } \\
\text { waterfall or not } \\
\text { 2. Making road signs how to } \\
\text { go to Curug Pulosari } \\
\text { 3. Online marketing } \\
\text { 4. English speaking guide }\end{array}$ \\
\hline Bukit Pajagan & $\begin{array}{ll}\text { 1. } & \text { Hiking } \\
\text { 2. } & \text { Bicycling } \\
\text { 3. } & \text { Enjoying the view }\end{array}$ & $\begin{array}{l}\text { 1. Fresh air, silent place } \\
\text { 2. Nice view from height } \\
\text { 3. No road signs to reach the } \\
\text { destination, only the map } \\
\text { of Krebet Tourism Village } \\
\text { 4. No facilities }\end{array}$ & $\begin{array}{l}\text { 1. Waste management is } \\
\text { needed to keep the place } \\
\text { clean } \\
\text { 2. } \begin{array}{l}\text { Road signs and warning } \\
\text { signs are needed }\end{array} \\
\text { 3. Sun shield built would be } \\
\text { great, such as simple roof } \\
\text { or trees plantation } \\
\text { Could be a nice place to } \\
\text { picnic with some basic } \\
\text { facilities such as toilet, } \\
\text { food stall, and safety }\end{array}$ \\
\hline $\begin{array}{c}\text { Pohon Krebet } \\
\text { and Semar }\end{array}$ & $\begin{array}{ll}\text { 1. } & \text { Krebet Tourism } \\
\text { Village's icon } \\
\text { 2. Historical visit }\end{array}$ & $\begin{array}{l}\text { 1. Welcoming sign to Krebet } \\
\text { Tourism Village } \\
\text { 2. Near Batik Wooden Craft } \\
\text { shops and Batik Wooden } \\
\text { Craft learning class }\end{array}$ & $\begin{array}{l}\text { 1. Need to build some } \\
\text { additional icons nearby to } \\
\text { attract more visitors } \\
\text { 2. Would be more clear if } \\
\text { there is a story of Krebet }\end{array}$ \\
\hline
\end{tabular}




\begin{tabular}{|c|c|c|c|}
\hline Location & Recreational Activities & Environmental Conditions & Development Needs \\
\hline $\begin{array}{l}\text { Krebet Tourism } \\
\text { Village's Main } \\
\text { Road }\end{array}$ & $\begin{array}{l}\text { 1. Watching Upacara } \\
\text { Merti Dusun, the } \\
\text { village's ceremonial as a } \\
\text { grateful of life and } \\
\text { prosperity }\end{array}$ & $\begin{array}{l}\text { 1. Seasonal celebration in } \\
\text { Javanese tradition } \\
\text { 2. No sun shield except trees } \\
\text { that planted irregularly on } \\
\text { daylight, not enough light } \\
\text { at night time. }\end{array}$ & $\begin{array}{l}\text { Village that is written and } \\
\text { explained in there } \\
\text { The schedule of the } \\
\text { celebration (Upacara } \\
\text { Merti Dusun) should be } \\
\text { announced on social } \\
\text { media } \\
\text { 2. Plant or build sun shield } \\
\text { to make the audience feel } \\
\text { more comfortable } \\
\text { 3. Seasonal food stall will } \\
\text { support the event }\end{array}$ \\
\hline $\begin{array}{l}\text { Batik Wooden } \\
\text { Craft Workshop }\end{array}$ & $\begin{array}{l}\text { 1. Shopping Batik Wooden } \\
\text { Craft products } \\
\text { 2. Window shopping } \\
\text { 3. Watching the making of } \\
\text { Batik Wooden Craft }\end{array}$ & $\begin{array}{l}\text { 1. Not all the shops have } \\
\text { clear Shop Sign } \\
\text { 2. No road sign to go to each } \\
\text { shop } \\
\text { 3. Old map } \\
\text { 4. Unavailability information } \\
\text { about the shops on the } \\
\text { internet }\end{array}$ & $\begin{array}{l}\text { 1. Need clear and big shop } \\
\text { sign on each shop } \\
\text { 2. Need road signs to reach } \\
\text { each shop } \\
\text { 3. Need to update the } \\
\text { Krebet Tourism Village } \\
\text { Map when there is new } \\
\text { information to add on } \\
\text { There is should be a } \\
\text { Shops list on the internet } \\
\text { with their opening hours. }\end{array}$ \\
\hline $\begin{array}{l}\text { Sekretariat Desa } \\
\text { Wisata Krebet } \\
\text { Pajagangan }\end{array}$ & $\begin{array}{l}\text { 1. Practicing how to make } \\
\text { Batik Wooden Craft }\end{array}$ & $\begin{array}{l}\text { 1. Professional mentor } \\
\text { 2. Lack of the stories behind } \\
\text { the product }\end{array}$ & $\begin{array}{l}\text { 1. Need more information } \\
\text { about the package } \\
\text { 2. Should add histories and } \\
\text { stories about the product } \\
\text { to make it more valuable } \\
\text { 3. English speaking mentor }\end{array}$ \\
\hline
\end{tabular}

Source: Data Collecting (2019), the table was adopted from Astuti \& Noor (2016)

Access to Krebet Tourism Village is easy to reach. The location is convenient because of help from the road sign on the main road. Table 2 informs that using private vehicle is the easiest way to arrive at Krebet Tourism Village. Thus some companies provide rent for cars and motorcycle so that visitors are able to come to many tourist attractions in town. The second option would be the online taxi, although it is difficult to call the taxi from the village since the location is far from the crowd.

However, on some points, the road condition is bad. Broken roads are dangerous, especially on rainy days. This should be attention for the government to increase the visit of this tourism village. Public transportation that focuses on tourism should have been provided by the government also. The fact tells distance from airports and train stations that bring people from outside of this province is far. The scope of public transportation is not capable to reach many tourist destinations in this province, except vehicle rental which is not cheap if the visitor is on a solo tour. By providing public transportation to tourist attractions, not only will attract more visitors, this easier way will expand the target market. Local people who unable to use private vehicles can visit Krebet as their leisure.

The inbound tour operator also plays a role to bring more tourists in. Many international tourists come to Krebet Tourism Village as a reseller of Batik Wooden Craft. In this way, Batik Wooden Craft made in Krebet is sold internationally. On one hand, the inbound tour operator has not collaborated with this tourism village since the schedule of tourist attractions that available on this village is still unsure. If there are the exact schedule and complete information about the service that Krebet provides, this tourism village will be added to the inbound tour operator's trip choice list. Accordingly, visiting Krebet Tourism Village will be the holiday plan when visiting Yogyakarta Province.

To visit all the places at Krebet Tourism while staying there will be easier using a bicycle. The distance between some tourists attraction to another is not far, thus the visitors will be able to do window shopping at many shops. Besides, Bukit Pajangan is the place for bicycling. People bring their own bicycles so far, hence, if the tourists do not have one, they will unable to explore the village well. Bicycles will be a good facility to provide. 
Table 2 Accessibilities to Krebet Tourism Village

\begin{tabular}{|c|c|c|c|}
\hline Accessibility & Condition & Reliability & Environmental Sustainability \\
\hline Main Road & Some broken road & $\begin{array}{c}\text { Have to wait for another } \\
\text { vehicle to pass }\end{array}$ & Clean but unsafe \\
\hline \multirow{2}{*}{$\begin{array}{c}\text { Support Road } \\
\text { Another Way to Reach the } \\
\text { Destination }\end{array}$} & New Concrete-road & Slippery on a rainy day & Clean and safe when dry \\
\hline & Bad & $\begin{array}{l}\text { Unreliable when using a } \\
\text { vehicle }\end{array}$ & Clean \\
\hline Airport & $\begin{array}{l}\text { 25.4 kilometers from Adi Sucipto } \\
\text { International Airport } \\
\text { 36.4 kilometers from New } \\
\text { Yogyakarta International Airport }\end{array}$ & $\begin{array}{l}\text { Reliable } \\
\text { Reliable }\end{array}$ & $\begin{array}{c}\text { Crowded } \\
\text { Orderly and Safe }\end{array}$ \\
\hline Vehicle Rental & Available & Reliable & Fair price and safe \\
\hline Conventional Taxi & Available & $\begin{array}{l}\text { Taxis are unavailable } \\
\text { sometimes, } \\
\text { Difficult to call a cab from } \\
\text { the village }\end{array}$ & More expensive \\
\hline Inbound Tour Operator & $\begin{array}{l}\text { Some hotels in Yogyakarta Province } \\
\text { provide it } \\
\text { Provided by some tour and travel in } \\
\text { town }\end{array}$ & Reliable in order & $\begin{array}{l}\text { Higher price } \\
\text { Give more information about } \\
\text { regional tourism }\end{array}$ \\
\hline Bus Shelter & $\begin{array}{l}\text { 13.7 kilometers from Giwangan Bus } \\
\text { Shelter }\end{array}$ & The Schedule is not on time & Crowded, Stuffy, and Dirty \\
\hline Train Station & $\begin{array}{l}\text { 13.4 kilometers from Tugu Train } \\
\text { Station } \\
\text { 17.2 kilometers from Lempuyangan } \\
\text { Train Station }\end{array}$ & Reliable & Crowded \\
\hline Harbour & Not Available & & \\
\hline Bicycle & Not Available & & \\
\hline Online Taxi & Available & $\begin{array}{c}\text { Difficult to call from Krebet } \\
\text { Tourism Village }\end{array}$ & Fair price and safe \\
\hline
\end{tabular}

Source: Data Collecting (2019), the table was adopted from Astuti and Noor (2016)

Table 3 Amenities in Krebet Tourism Village

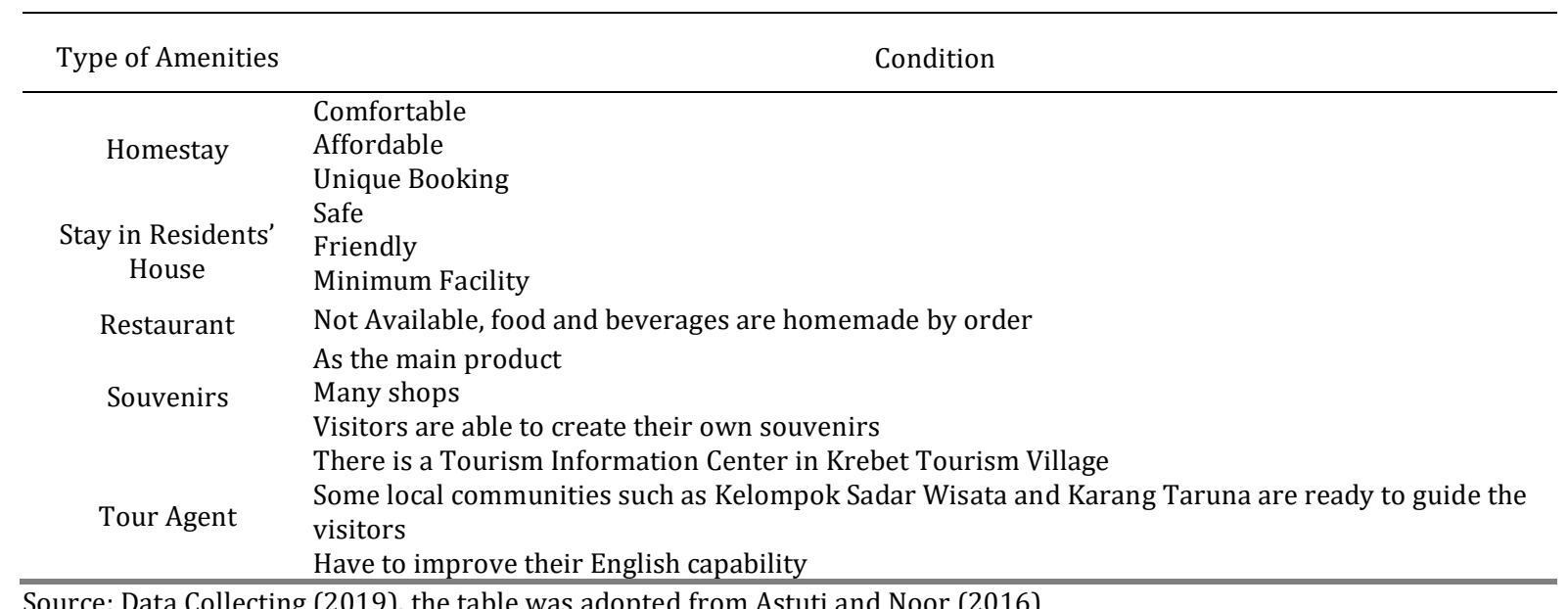

Source: Data Collecting (2019), the table was adopted from Astuti and Noor (2016)

Ancillary plays a vital role in order to develop tourism destinations. This aspect is an indicator of whether a destination is a safe place, comfortable to meet sustainable tourism. The result of the ancillary investigation in Krebet Tourism Village is reported in Table 4. Krebet Tourism Village has not met the standard. Even though police are available, the distance to firefighter and health service are quite far. This tourism village should provide first aid and fire hydrant to minimize risk. The trash can is needed in purpose for minimizing littering. Toilet also a vital thing to adjust with the minimum standard. The current toilet is confusing to use. Sink, toilet seat, and light should be available. However, the condition is clean. In spite of the disadvantages, the phone signal is good for the telephone and the internet, the quality of water 
is good, and some shops provide card payment. The ancillaries in Krebet Tourism Village should be informed at their website, thus the visitor can be prepared.

Table 4 Amenities in Krebet Tourism Village

\begin{tabular}{|c|c|}
\hline Type of Ancillary & Condition \\
\hline & Available \\
\hline Police & Stand by when an event in ongoing \\
\hline \multirow[b]{3}{*}{ Roads } & Broken roads on some points \\
\hline & There are traffic sign stand on \\
\hline & No specific road signs to go to each Batik Wooden Craft Shop \\
\hline Health Service & Community Health Center is available, 4.7 kilometers away from the village \\
\hline \multirow[t]{2}{*}{ Firefighter } & 7 kilometers away \\
\hline & Not enough light \\
\hline \multirow{3}{*}{ Toilet } & Clean \\
\hline & No toilet seat \\
\hline & No sink \\
\hline \multirow{3}{*}{ Waste Treatment } & Lack of trash can \\
\hline & In progress to fins the best way to minimalize dust from raw wood \\
\hline & The residents are adapting strain system by using plants to keep the water in the best quality \\
\hline \multirow{2}{*}{ Water } & Good quality \\
\hline & Lack of water when dry season \\
\hline \multicolumn{2}{|c|}{ Communication NetworkAvailable network for phone and internet } \\
\hline Banking & $\begin{array}{l}4 \text { kilometers away from ATM } \\
\text { Card payment is available in some shops }\end{array}$ \\
\hline
\end{tabular}

\subsection{Krebet Tourism Development Effort}

The visitors of Krebet Tourism Village are not only from Indonesia but also international. Based on Table 5, domestic tourists dominate the visit. Only 9 shops are visited by international tourists. It depicts that the international approach to introduce Krebet Tourism Village has to be improved. It is related to the main problem aforementioned, this tourism village needs to gain their communication in English to scope the larger market. Despite, there are a big number of local tourist.

From the number of visits, most of the shops got a small number. This data should be a reflection of why there are shops with a big visit while the majority are not. It could be because there are no road signs that lead the way to find specific shops rather than shops located on the main road. The availability of products could be another reason. Visitors tend to come to a shop that sells more complete items. Again, the internet has not been used maximally.

Table 5 Visitors in Krebet Tourism Village

\begin{tabular}{ccc}
\hline Characteristics & Category & Number of Shops \\
\hline \multirow{2}{*}{ Tourist Origin } & Domestic & 30 \\
& International and Domestic & 7 \\
Number of Visit & International & 2 \\
& Less than 10 people & 23 \\
& Mo to 25 people & 1 \\
& More than 25 people & 10 \\
Recreational Activity & Shop Batik Wooden Craft & 33 \\
& Observing Batik Wooden Craft making process & 23 \\
& Making Batik Wooden Craft & 20 \\
& Enjoying Meal and/or welcome drink & 4 \\
& Sightseeing the views & 3 \\
& Stay for a few days & 3 \\
\hline
\end{tabular}

Source: Data Collecting (2019), the table was adopted from Astuti and Noor (2016) 
To serve the visitors, there are only 3 shops that provide complete service and information. Basically, the views and local performance are available for the entire residents, however, without support facilities and information, the tourists are incapable to enjoy another tourism potentials of Krebet Tourism Village if the services are limited.

Based on Table 6, there is Batik Wooden Craft making process class as the only tourism package offered by Krebet Tourism Village. For around 30 years, Krebet has been establishing its Batik Wooden Craft business, this tour package effectively brings many people to come into Krebet Tourism Village from early child age until elder. This activity is mainly an educative, besides it also relaxation for those who love art. Hence, Krebet Tourism Village has no clear package for homestay or live in. Whereas this kind of package will call more economic value for the village. Also, the chance to promote the village will be wider.

Table 6 Krebet Tourism Development Effort

\begin{tabular}{|c|c|}
\hline Effort & Additional Information \\
\hline Tourism Package & $\begin{array}{l}\text { Batik Wooden Craft making process class } \\
\text { Food and beverages }\end{array}$ \\
\hline Additional Facilities & $\begin{array}{l}\text { Toilet } \\
\text { Praying room } \\
\text { Pavilion } \\
\text { Local: local events, Shopping Center, Local Attraction Event, etc }\end{array}$ \\
\hline Trade Fair Participation & $\begin{array}{l}\text { National: Bali, Sumatera, Jakarta } \\
\text { International: Australia, United States, China, etc }\end{array}$ \\
\hline Online Marketing & $\begin{array}{l}\text { Website } \\
\text { Business Management Training }\end{array}$ \\
\hline Training Participation & $\begin{array}{l}\text { English Training } \\
\text { Web Design Training } \\
\text { Design Training }\end{array}$ \\
\hline
\end{tabular}

Source: Data Collecting (2019), the table was adopted from Astuti and Noor (2016)

For the additional facilities, the need to be corrected is the toilet. As a destination, they should provide standard hygiene with a sink. Another effort to promote Batik Wooden Craft is by joining some fair that use to be sponsored by the local government and some companies. This promotion event is successful to increase the sales of Batik Wooden Craft, nevertheless, the fair participants never promote the tourism village as their tourism potential. Perhaps the fair will also increase the number of visitors who come to enjoy the village not only purchase the wooden craft.

Further, the website is not updated and the information is incomplete. Krebet Tourism Village should tell more about all the tourist attractions they have, including the schedule of their yearly ceremonial event and local performance. When making road signs takes a longer time, the website can be information on how to reach each tourist attraction and each shop located at Krebet Tourism Village. The history also an important thing to add to the website, since Krebet Tourism Village could be categorized as a heritage. Lastly, the training program they have joined in order to develop Krebet Tourism Village. All the training they have are things they need to improve. Except for the product design, knowledge for managing and communicating are the key success for a business. Particularly, English is the basic thing they should use for serving international consumers.

\section{Conclusions}

Analysis of tourism components has identified Krebet Tourism Village has tourism potentials in a natural tourist attraction, heritage, local event, and local performance besides their main product, Batik Wooden Craft. Curug Pulosari has the potential as another signature tourism. Followed by the event and performance. For the purpose of making Krebet Tourism Village tourism potentials get an increasing number of visits, this tourism village should meet the minimum standard of tourism components (attractions, accessibilities, amenities, and ancillaries). Thus, they should be able to communicate with English; add some supportive facilities such as sun shields, food, and beverages, trash can, standardize toilet, first aid and fire hydrant, and road signs; and keep updating the information about Krebet Tourism Village at their website at least.

Their efforts in developing Krebet Tourism illustrated the effort has not optimized. Krebet Tourism Village needs maintenance, improvement, and continuity on their effort, particularly on the facilities and 
communication. They need to add a homestay package so that cultural understanding will be created among visitors as the main purpose of the tourism village establishment. Other than that, tourism village marketing through fairs will catch more visitors.

Acknowledgment We thank the Directorate of Research and Community Service; Ministry of Research, Technology, and Higher Education through research funding and community service for the 2017-2019 fiscal year which have provided stimulant funds. We would also like to thank UGM Tourism Study Center, a guest speaker at the Krebet tourism village, who provided valuable input for this research

\section{References}

Astuti, M. T., \& Noor, A. A. (2016). The attractiveness of Morotai as historical and marine tourism destination. Indonesia Tourism Journal, 11(1).

Cooper, C., Fletcher, J., Gilbert, D., Fyall, A., \& Wanhill, S. (2005). Tourism: Principles and practice. UK: Pearson Education.

D.I. Yogyakarta Bank Indonesia Regional Office. (2018). D.I. Yogyakarta Province Economic Development in 2018 Annual Report. Retrieved from https://www.bi.go.id/id/publikasi/kajian-ekonomiregional/yogya/Pages/Kajian-Ekonomi-dan-Keuangan-Regional-DIY-November-2018.aspx

Garrod, B., \& Fyall, A. (2000). Managing heritage tourism. Annals of Tourism Research, 27(3), 682-708. https://doi.org/10.1016/S0160-7383(99)00094-8

Tosun, C. (2000). Limits to community participation in the tourism development process in developing countries. Tourism Management, 21(6), 613-633. https://doi.org/10.1016/S0261-5177(00)00009-1

Tourism Department of Yogyakarta. (2017). Statistics Book of D.I. Yogyakarta Tourism in D.I. Retrieved from Yogyakarta Tourism Statistical Report 2017 website: https://visitingjogja.com/15691/statistik-pariwisatadiy-2017/ 